\title{
KML を用いた氾濫計算可視化の高度化
}

\author{
田中 甫幸 1 - 井上 卓也 2 - 清水 康行 3 \\ 1 正会員＼cjkstart国土交通省水管理・国土保全局河川計画課（テ100-8918 東京都千代田区霞が関 2-1-3) \\ E-mail: tanaka-t22at@mlit.go.jp \\ 2 正会員 国立研究開発法人 寒地土木研究所 寒地河川チーム ( \\ E-mail: inoue-t@ceri.go.jp \\ 3 正会員 北海道大学大学院工学研究院教授 \\ ( $\bar{\top} 060-0813$ 札幌市北区北 13 条西 8 丁目) \\ E-mail: yasu@eng.hokudai.ac.jp
}

\begin{abstract}
災害から身を守るためには，災害時に適切な対応がとれるよう，災害時の状況をイメージすることが重 要であると考える。しかし平時から災害時の世界をイメージすることは難しい。本研究では, 災害時のイ メージを再現し, 自分の住む土地のリスクを直感的に把握することができる手法を検討した. 氾濫計算結 果のデータより緯度経度等の位置座標を定義し，三次元化したポリゴンを生成する方法で KML 化するこ とで, Google Earth や Street View に浸水範囲や浸水深を表示させ，浸水時の世界を自由に探索することを 可能にする可視化手法を構築した.
\end{abstract}

Key Words: Flood, Visualization, KML, Google Earth, Google Street View

\section{1. はじめに}

\section{(1) 背景}

2011年3月 11 日に日本を襲った東日本大震災，2013年 の伊豆大島の豪雨による土砂崩れ，2015年の関東・東北 豪雨， 2016 年 8 月に北海道・東北等を襲った台風 10 号 等，未曾有の災害が近年多発している。防災対策におい てはハード，ソフトの対策があるが，ハードだけでは未 曾有の災害に対応するのは困難であり，それを補うソフ 卜対策の充実が不可欠である.

治水安全度が低かった時代においては，洪水等の災 害が身近で発生していたこともあり，災害を経験した人 も多く，その経験は子供たちに伝承されており，避難の ための具体的な行動についても住民一人一人が共有でき たと考えられる。しかしながら，現在は安全度が大幅に 高まり，水災害に見舞われる頻度が大幅に低下した。 そ れにより水災害を経験したことがない人が増加した。

災害から身を守るためには，平常時からの防災対策 や，災害時の避難等が重要になってくる. その際, 適切 な対策や適切な避難を行うためには，災害時の状況をイ メージすることが重要と考える。しかしながら，安全度 が上がっている今の状況から経験したことがない災害時 の世界をイメージすることが難しい. また，近年，想定 外，未曾有の災害が発生している．そのような数百年に 一度と言われる災害をイメージすることは更に難しい.

\section{(2) 目的}

災害から身を守るためには，災害時の状況をイメー ジすることが重要であると考える，本研究では，災害時 のイメージを再現し，自分の住む土地のリスクを直感的 に把握することができる手法，またその共有手法を検討 する.

\section{2. 災害情報の現状と課題}

\section{（1）解析技術 ・メッシュ精度の向上高度化}

コンピュータによる解析技術が進み，LPデータ等の 解析の基盤となる情報の整備も進みつつある.このよう な技術的進歩によって，より高精度な氾濫計算や検討が 行われるようになり，今までは解析することができなか つた詳細なリスクについて把握できるようになりつつあ る. 例えば $5 \mathrm{~m}, 10 \mathrm{~m}$ のメッシュ等の細かいメッシュを 用いて高精度な計算が可能になった。

\section{(2) 三次元のデータの可視化の課題}

細かいメッシュを用いて氾濫計算を行った計算結果が 持つ情報量は莫大だが，その細かいメッシュが持つ情報 をどう活用するかが重要となってきている．氾濫計算結 果の可視化においては，浸水深等を三次元的に表現する ことは可視化ソフトを用いて容易に可視化することがで きる.しかし，汇濫計算は地理情報等の情報との関連付 


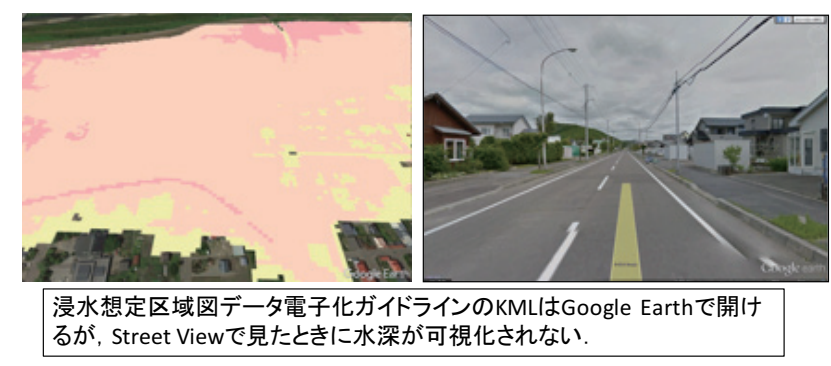

図-1 電子化ガイドライン KML ファイル

けが重要だが，単なる浸水深の可視化だけでは，地理情 報等との関係が分からない.

地理情報と関連付けるために二次元の可視化の場合は, 地図情報を背景にし，浸水深をコンター化した可視化結 果を投影することで関連付けを行うのが一般的だが，三 次元の浸水深の可視化は，その浸水深データの持つ情報 を活用するためには，地図等への投影だけでなく，背景 となる地理情報も三次元であることが重要である.

$5 \mathrm{~m}$ メッシュ等の細かいメッシュになると，地図には 落とし込めないより詳細な情報が含まれている，そのた め，地図だけではなく，多くの情報を提供できる，衛星 画像や街並みの写真等の情報が重要となってくる.また 浸水情報は受け手によって欲しい情報が異なる．三次元 の可視化データを用いた動画はこれまでにも作られてい たが，個々人が自宅周辺や通勤経路等の情報を知りたい 場合は視点場の変更が困難なことから，各ユーザーにカ スタマイズされた情報の提供は難しかった.

新しい浸水想定区域図データ電子化ガイドライン（第 2版，2015年 7月）では, 後述する GoogleEarth で展開で きる KML（Keyhole Markup Language）ファイルの作成が 義務づけられている。しかし，電子化マニュアルの KML ファイル作成方法では，水深情報を Street View ${ }^{2}$ 機 能を用いて三次元的に見ることができず（図-1），従来 の二次元的の可視化方法と大きく変わらない.

情報を受取る側は洪水の際に，何が浸かるのかを具体 的にイメージできれば，その情報を元に次の行動や対策 を推察できるようになると考える. 自宅は浸かるのか, 浸かると寸ればじこまで水位が上がる可能性があるのか, 車は浸かるのか, いつも使っている道は浸かるのか.こ れらの情報は浸水想定区域図等で用いられている二次元 の浸水深ごとのコンター図からは直感的にイメージしづ らい情報である.

高精度の氾濫計算結果の可視化においては, 単に浸水 域を三次元的に可視化するだけでなく，可視化した浸水 域・浸水深と地理情報等の他の情報との関連性，ユーザ 一の視点場にカスタマイズされていることが重要であり, それを実現する手法が課題であると考える.VR（Virtual Reality）技術を利用した可視化手法 ${ }^{3}$ や，AR（Augmented Reality）技術を利用した可視化手法 ${ }^{4}$ がこれまでにも提
案されているが，地形情報，建物情報等の生成にあたり， コストが発生したり, カメラ等で街並みと水深データを 重㸚合わせる場合はその場に赴く必要があったりした。

\section{3. 計算結果の KML 化について}

\section{(1) Google Earth の活用}

上述の課題に対し, 浸水域と浸水深を Google 社の Google Earth 及び Street View 上の仮想現実空間に浸水深と 浸水域を投影寸ることを試みた。 GoogleEarthにおいては, 建物や町並み等の三次元モデルが整備されている他，無 料でその情報を活用できる．また，地球を探索するよう な形で, 平面的な眺め, 鳥瞰的な眺め, 街角からの眺め を自由な角度から閲覧できる．街角の眺めを 360 度閲覧 可能な写真で整理された Street View 等の機能が整備され ており，活用できるため，計算結果を Google Earth 一投 影することを図った。

\section{(2) KML とそのメリット}

Google Earth に投影寸るためには，KML でその内容を 定義する必要がある．KML とは，Google Earth によって 広められた, XML ファイルの一つである. KML を圧縮 したファイルを KMZ といい，その 2 種類が主に Google Earth上での表現に使われる.

ウェブブラウザが HTML ファイルを表示するのと同 様に, Google Earth などの Earth ブラウザは KMLファイル を表示することができるため, Google Earthをインストー ルすれば，KMLや KMZファイルを閲覧することができ る。またそれらのファイルは，また， Google Earth や Google Map を始め, 地理院地図（電子国土Web）など多 くのアプリケーションが KMLの表示に対応している.

KMLやKMZファイルを共有するには，メールで送付， ローカルネットワーク内で共有, ウェブサーバー上で公 開するなどの方法がある. また，近年ではスマートフォ ンやタブレットが普及しているが，それらの端末におい ても Google Earth のアプリケーションをインストールし， KML化したデータを見ることができる.

KML化のメリットとして,

(1) KML化により可視化の定義や煩雑な設定なしに Google Earth上で計算結果を表示が可能.

(2) 時間毎に計算結果の表示が可能であり, 動的な解 析結果を表示可能.

(3) 浸水深をコンターだけでなく, 水深・水位を三次元 で表示となるため, 建物等との相対的な高さを直 感的に知覚できる. 


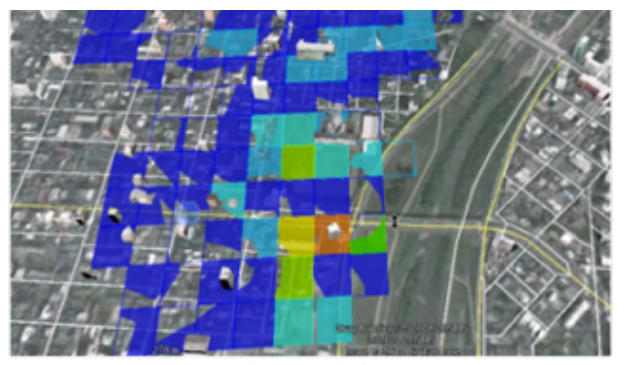

荒いメッシュ(視点が離れている場合)

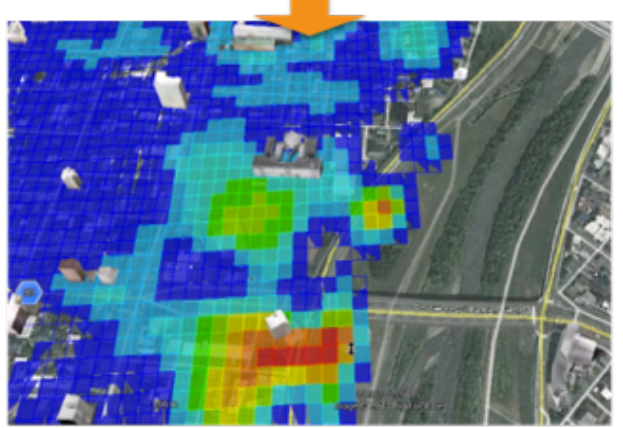

細かいメッシュ(視点が近づいている場合)

図-2 視点によるメッシュの細度の変化

(4) StreetView上で計算結果を表示寸ることで, 街角か らの眺めに汇濫時の光景を投影することが可能.

(5) 共有が容易.

(6) 他のKML化されたオープンソースを活用可能 が挙げられる.

\section{(3) KMLの可視化手法}

KML の可視化手法は以下の 3 つに分類できる.

(1)計算結果画像を KML化

計算結果から出力した二次元コンター図等の画像に 位置座標を定義し，KML 化する手法である。しかしな がら，ラスタ画像となるため，領域を拡大すると，画像 が粗くなる．その対策として，画像をタイル化して，拡 大領域にあわせて表示することも可能だが，各拡大域に その KML化した画像を生成する必要がある.

(2)計算結果のデータを二次元ポリゴン化し KML化

計算結果のデータより緯度経度等の平面方向の位置 座標を定義し，二次元化したポリゴンを生成する方法で ある. しかし，二次元情報のため，水深等の垂直方向の 情報はポリゴンに含まれていないため，可視化の際はコ ンター図等で水深等の垂直情報を表現する必要がある.

また，(1)の手法と比較して，KML データがベクトル化 されているため，拡大しても KML 化した結果が粗くな ることはない，なお，浸水想定区域図の KML データは 二次元のポリゴン化した KMLである5).

(3)計算結果のデータを三次元ポリゴン化し KML化

計算結果のデータより緯度経度等の平面方向の位置 座標を定義に加え, 水深等の垂直方向の情報を加えて, 三次元化したポリゴンを生成する方法である. 今回の検

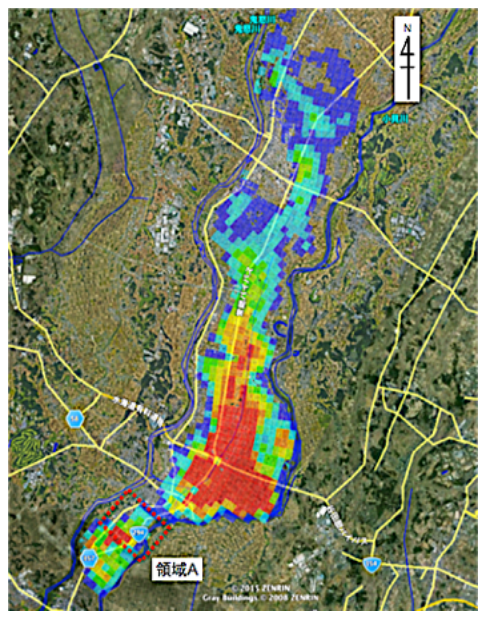

図-3 ケース aにおける可視化結果の平面図

討では，KML 化の三次元化に取り組んだ。詳細は 3.(4) に記載する. 三次元化に伴い, データ量が大きくなるた め, メモリの扱いが重要となる.

\section{(4) KML ファイルの作成と共有}

$\mathrm{iRIC}^{6}$ )で行った計算結果の座標（平面直角座標系）を 緯度経度に変換し，KML の記載方式に従い出力し，三 次元のポリゴンを生成した可視化ファイルを作成した.

この KML 作成の作業を効率化するため, iRIC の CSV 形 式による計算結果出力形式からに KML 変換できるプロ グラムを作成した．なお，変換のフローは以下のとおり．

(1) iIRICの計算結果をCSV形式により出力.

(2) KML化し，Google Earth等に投影寸るためには，座標 を緯度経度に変換する必要がある. iRIC出力した計 算結果の座標を緯度経度に変換.

(3) 計算格子毎に格子の 4 点の緯度経度, 水深(もしくは 水位)情報を反映し，ポリゴンと呼ばれるKMLの要素 を作成.

(4) 指定したスケール毎にカラーコンターを定義し, 水 深に対応したコンターをポリゴンの色に反映.

(5) タイムスタンプ機能7)活用し, 時間毎に整理され たポリゴンデータを読込。

また，Google Earth 上への計算結果の反映にあたって は,メモリの扱いが重要である. 計算領域が大きかった り，メッシュが細かったりすることで，出力される計算 結果が大きい場合，それを一度に Google Earth に表示さ せるとメモリ不足になり，動作が遅くなったり，フリー ズ等の症状が派生する.

それを防ぐため，データの境界ボックスを定義する ことで, Region を操作 ${ }^{8)} し$, 自らの視点からポリゴンが 離れた際には, 細かいメッシュで作成したポリゴンをメ モリから開放し，荒いメッシュを読込み，自らの視点が 近づいた際には細かいメッシュのポリゴンを読み込む工 夫を施した. (図-2参照) 


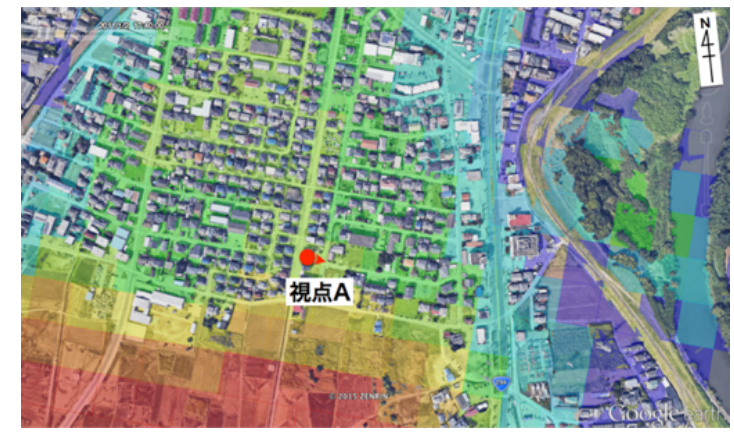

図-4 ケース $\mathrm{a}$ 領域 $\mathrm{A}$ における可視化結果の平面図

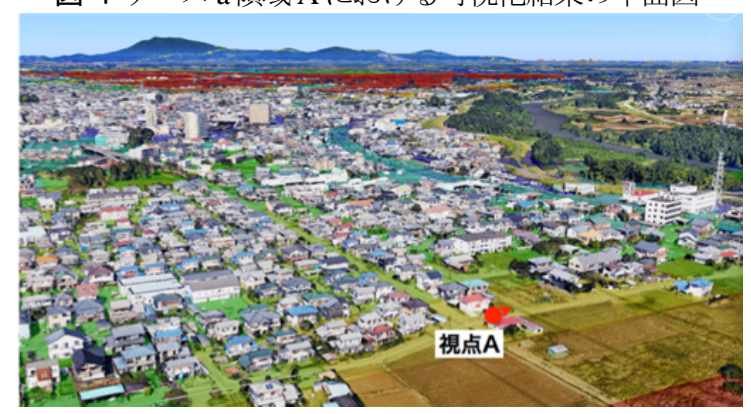

図-5 ケース $\mathrm{a}$ 領域 $\mathrm{A}$ における可視化結果の鳥瞰図

\section{KML 化した出力結果とその考察}

\section{(1) 再現計算}

氾濫計算を実施し，その結果を KML で可視化したも のを作成した.今回はあくまで可視化の高度化について 取り上げるために実施した計算のため，流量・水位等に ついては，特段根拠のあるデータを使用していない．汇 濫の特徴が異なる箇所で以下の 4 ケースで計算を実施し た.

・ケースa : 郊外の汇濫原における浸水 常総市付近で起きた鬼怒川破堤を想定.

・ケースb : 都市部における浸水 札幌市における破堤を想定した汇濫計算を実施.

・ケースc : 農作地における浸水 農作地での中小河川の氾濫を想定．場所は北海道 十勝地方における旧途別川の氾濫を想定.

\section{(2) 水害リスク}

汇濫の想定を行うにあたって, 汇濫計算を行う必要 がある．汇濫計算にはフリーソフトウェアである iRIC を用いた。

\section{(3) 地盤データ}

LP データや国土数值情報で用いられている平面直角 座標系のデータを使用し，計算は平面直角座標系の座標 を用いた。

\section{(4) ケースごとの計算結果}

詳細は出力画像ごとに以下で述べてゆく.

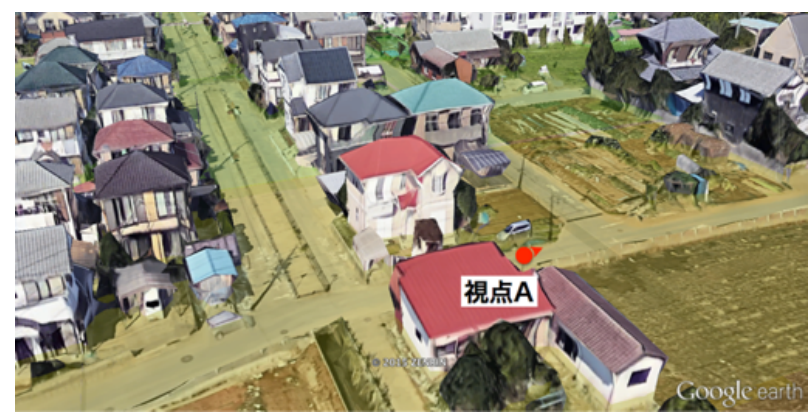

図-6 ケース a視点 $\mathrm{A}$ 付近における可視化結果の鳥㒈図

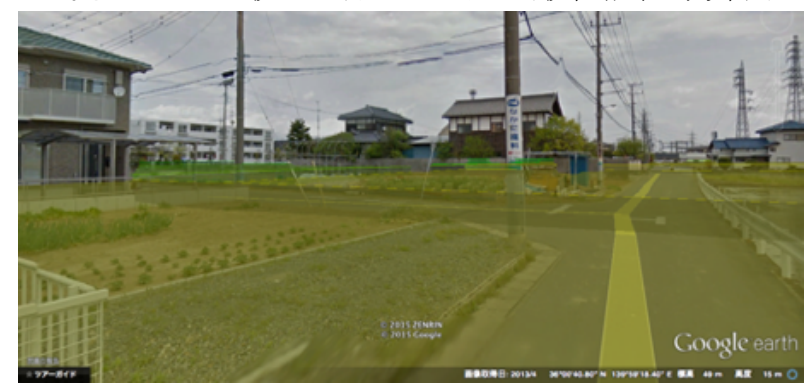

図-7 ケース $\mathrm{a}$ 視点 A における可視化結果(StreetView 表示)

\section{a) 郊外の汇濫原における浸水}

これは常総市における洪水を再現し，計算結果を KML 化し，Google Earth へ反映したものである. 図-3 は 平面的に見た図である. 計算結果の全体像を容易に把握 することができる，図-4 は領域 A を拡大したものであ る. ポリゴンというベクトル形式のブロックで計算結果 が Google Earth 上で可視化されているため，拡大した際 にも，基盤の地図情報や，浸水領域が鮮明に表示される ことが確認できる. 国土地理院の基盤地図情報など，さ まざまな KML レイヤーを活用することで，衛星画像以 外の地図等の KML 化されたオープンソースを活用する ことが可能である.

図-5 は鳥瞰図になる。鳥瞰図であると，三次元的な 情報となるため, より氾濫時の町並みをイメージするこ とが可能となる．あわせてランドマークとの位置関係等， 平面的な情報では分からない情報を直感的に得られるこ とができる．図-6 は視点 $\mathrm{A}$ を拡大した図になる.より 普段目にするスケールに近づく. 浸水の有無だけでなく, 浸水を表すポリゴンが高さ情報を持っているため, 浸水 深と建物の関係が容易に把握することができる．床上， 床下の浸水情報や，建物のどこまで水が浸かるかどうか という情報を得ることができる.

図-7 は Street View 表示にしたものである. ポリゴンに て出力することで，Street View 上に浸水時の世界を表示 することが可能である. 普段我々が目にする世界と同じ 目線で表示が可能となったことで，多くの情報が入手可 能である，例えば，家のどの高さまで浸かるかどうか, 家の周りでは何が浸かるのか, 歩行での避難が可能な水 深かどうか等の情報である。 


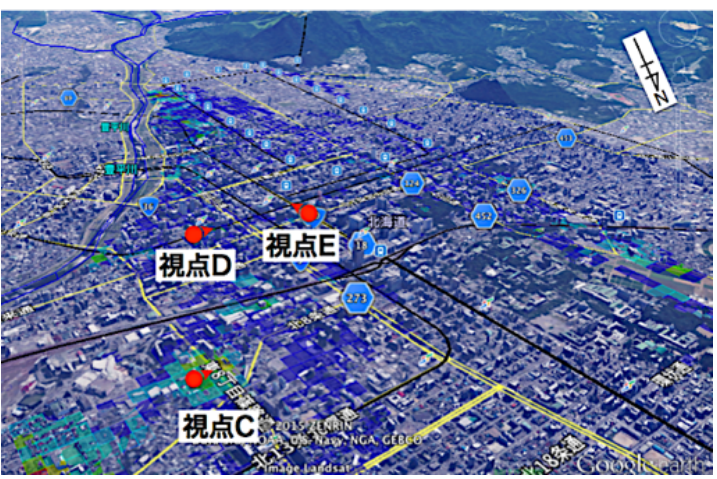

図-8 ケース $\mathrm{b}$ 可視化結果の鳥㒈図

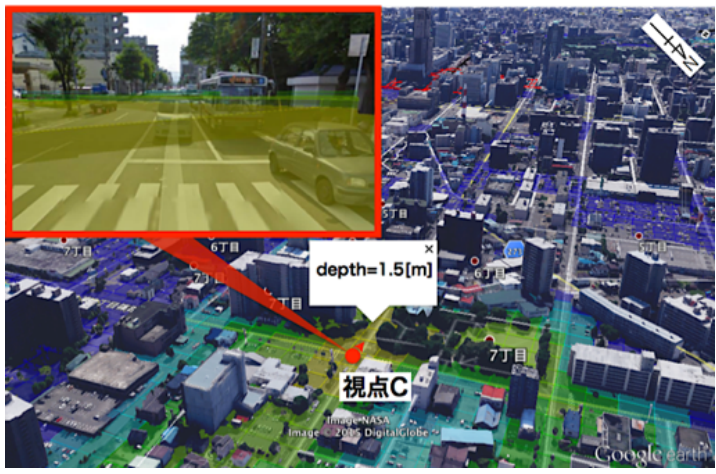

図-9 ケース $\mathrm{b}$ 視点 $\mathrm{C}$ 付近における可視化結果

\section{b) 都市部における浸水}

都市部における浸水を想定した計算を実施した。豊 平川が破堤したことを想定したイメージである．図-8 はその鳥㒈図になる．扇状地を汇濫水が流下寸る様子が 見て取れる，扇状地上にできた都市である札幌の汇濫に おいては，扇状地などに形成された凹地や浅い流路跡な ご，相対的に低い微地形が浸水範囲に影響する。図-9 においては，その凹地において，浸水範囲が確認できる. なお，該当箇所のポリゴンをクリックすると浸水深を表 示できるようにKMLを作成している.

Street View 表示をした際には，車両等が浸かる高さま で浸水することが分かることから，洪水時には通行でき なくなることが容易に推察される. 図-10 においては, 周囲の水深(青色)に比へ，緑色で示された異常に高い水 深があることが分かる，通常の可視化ソフトの場合，そ の高い水位の要因を検討することは難しいが， Google Earthで表示した場合は，容易に縮尺を変更することが 可能であり，また詳細な衛星画像と浸水範囲を重ねるこ とができることから，現地の情報を詳細に分析すること が可能である．この場合であると，地下駐車場への入口 であることが分かり，その結果，局所的に深い浸水深が 発生していることが見て取れる.

Google Earth においては，地下街等の地下構造物も示 される. 図-11 の赤線で示された箇所は地下構造物とそ の入口である.これにより地下構造物がどこにあり，そ の入口がどこにあるかを容易に知ることができる他，浸 水域と重ねあわせることで，その入口の浸水可能性やそ
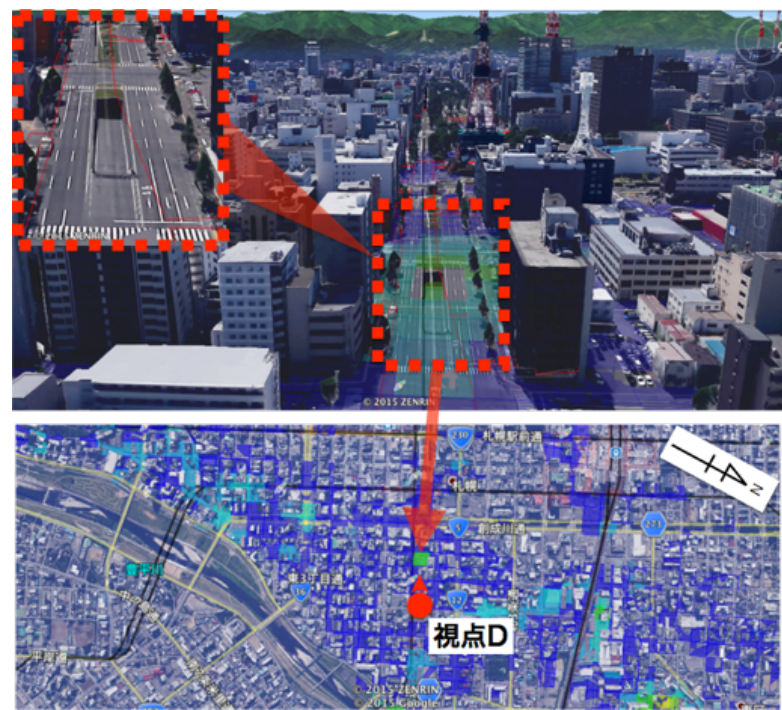

図-10 ケース $\mathrm{a}$ 視点 $\mathrm{D}$ 付近における可視化結果

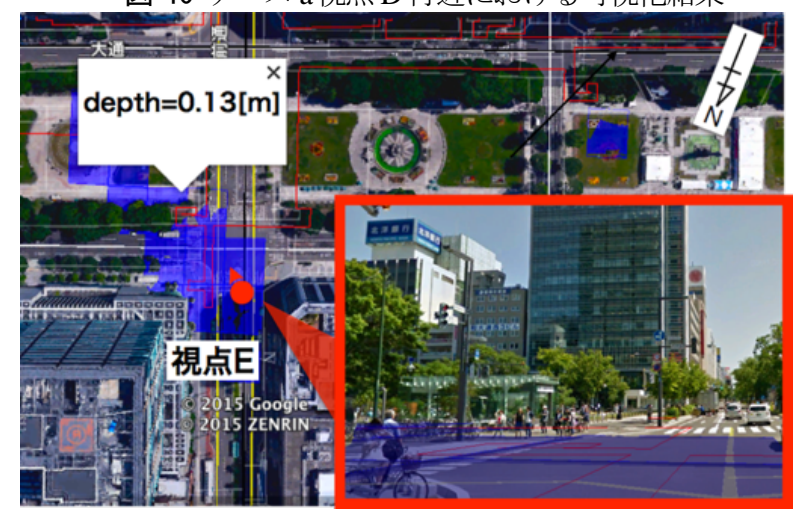

図-11 ケース $\mathrm{b}$ 視点 $\mathrm{E}$ 付近における可視化結果

の対策等を簡易的に検討できる．図-11 の場合であると， 地下街への入口近辺では, $10 \mathrm{~cm}$ 程度の浸水が想定され ており，洪水時には止水板や土囊等の対策をとることが 有効であることが推察される.

c) 農作地における浸水

図-12 は農作地における浸水をイメージしたものであ る. 浸水している箇所が田んぼか，畑かなどの判別や， 八ウスの有無等を確認することが可能である.

また，図-13では，詳細なメッシュを用いた際には， 平面図からでは判別しづらい，細かい構造物の止水効果 を判別することもできる.

\section{(2) 活用法の検討}

従来の八ザードマップのように紙媒体や PDF 等の電 子媒体で配布するだけでなく，インターネット上で KML 化したデータを配布することで，Google Earth を持 つユーザーが自由に閲覧・利用することで，防災の啓蒙 と対策に役立てることを想定している．Street View 等の 機能を用いることで，普段生活している目線から汇濫時 の水位を確認することができ，家の何階まで水位が上が るか, 避難所まで Street View 上でルートを辿っていくこ とで歩いて避難ができるような水位かどうか等，地図で 


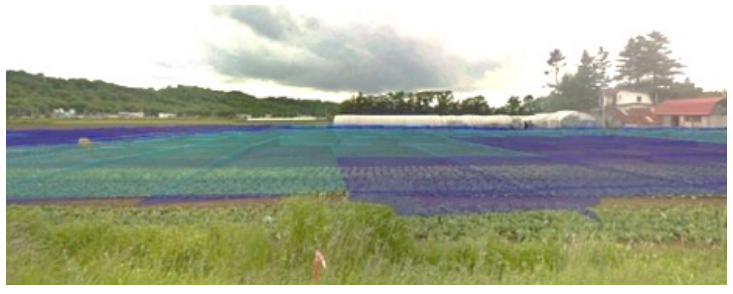

図-12 ケース cにおける可視化結果例 1

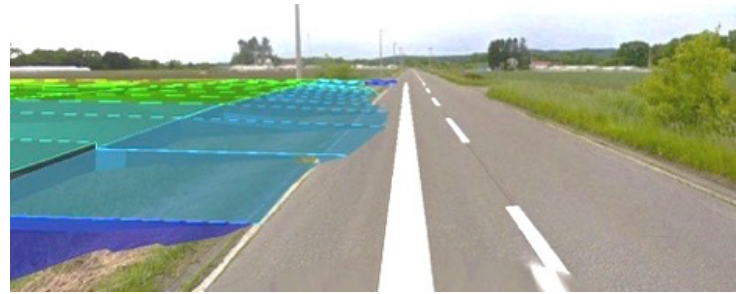

図-13 ケース cにおける可視化結果例 2

は直感的に分からない情報を得たり，避難の際のシミュ レーションの実施ができるようになると考える.

また，GPSが付いているタブレットやスマートフォン に Google Earth をダウンロードし，KML 化した計算結果 を，河川巡視時に持参することで，平常時の巡視を行い ながら，現場で水害時のイメージを示すことが可能にな る。それにより防災上の脆弱性の発見や，具体的な対策 に役立てるものと考える.

災害図上訓練の際，従来の紙の地図での訓練の他， Google Earth 上に KML 化した計算結果を投影し，よりリ アルなイメージを用いながら，水害時の図上訓練が可能 になる. 水害時の河川巡視や樋門・水門の操作を行う際 にどの取り付け道路を登って行けばよいのか，避難の際 にどのルートを通ることが有効なのか等のシミュレーシ ヨンが可能になる.

\section{5. おわりに}

災害から身を守るためには，災害時に適切な対応が とれるよう，災害時の状況をイメージすることが重要で ある，本研究では，氾濫計算結果を三次元ポリゴンを活
用した KML 化により，Google Earth や Street View に浸水 範囲や浸水深を表示し，浸水時の世界を自由に探索する ことを可能にする可視化手法を作成した。

これにより，ユーザーが知りたい場所へ自由に移動 することにより，浸水深時の世界を探索し，災害時のイ メージをつけることを容易にすることが可能となった.

また，Google Earth と Street View と連動することで，可 視化の表現力も大幅に向上し，ユーザーは町並みと浸水 域を重ねることにより，浸水範囲や浸水深やその時系列 ごとの変化等の情報だけでなく，具体的に何が浸かるの かを知覚可能になった．建物のどの位置がつかるかどう か，車両が浸かるかどうか，地下街への人口と水位の関 係，凹地や道路等の盛土が洪水時によ゙う影響するか等, 直感的に把握することが可能となった.

この KML 化技術については，iRIC へ実装される予定 であり，無償で活用できる予定である。

\section{参考文献}

1) Google Earth, http://www.google.co.jp/earth/

2) Google Street View, https://www.google.co.jp/intl/ja/streetview/

3) ARハザードスコープ概要, http://www.cadcenter.co.jp/camp/ARscope.html

4) 岩塚雄大, 古牧大樹, 西畑剛, 川辺赴史, 樫山和男 : 地域 防災教育のための 3 次元津波浸水解析とその可視化 に関する研究, 土木学会論文集 F3(土木情報学)Vol.70,No.2, pp152-159,2014

5) 浸水想定区域図データ電子化ガイドライン(第 2 版), pp5960, 国土 交通 省 , http://www.mlit.go.jp/common/001097667.pdf

6) iRIC, http://i-ric.org/ja/

7) 時間とアニメーション, KML 入門用ドキュメント, Google, https://developers.google.com $/ \mathrm{kml} / \mathrm{docu}-$ mentation/time?hl=ja

8) Regionの操作, KML 入門用ドキュメント, Google https://developers.google.com/kml/documentation/regions?hl=ja

(2016. 9.30 受付)

\section{THE IMPROVEMENT OF VISUALIZATION OF INUNDATION CALCULATION BY USING KML}

\section{Toshiyuki TANAKA, Takuya INOUE and Yasuyuki SHIMIZU}

It is important to imagine the situation of inundation to take appropriate majors to save our live from the hazard. However, it is difficult to imagine inundated world from ordinary time. In this research, we study the visualizing method to create inundated world which notice us the risk of the land intuitively.

We make the KML file which visualize the inundation area and depth from the calculated date by defining 3D polygon related to GIS data. And this KML file allows us to visualize the inundated area and depth on Google Earth and Street View which enable us to travel around the inundated would. By this visualization method, we are able to image the inundated would easily. 